\section{Acta 3iwlogica Gibirica}

Journal of Biology

Founded in 2015
Altai State University

www.asu.ru

ISSN 2412-1908

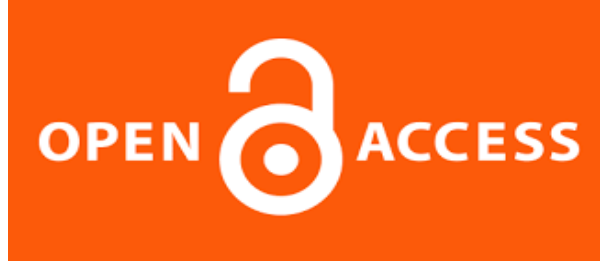

Acta Biologica Sibirica, 2017, 3(3), 23-31

UDC 574.9+911.9:502

\title{
Factors of the formation of landscape diversity of the natural park "Foothills of the Altai" and ways to preserve it
}

\author{
O.N. Baryshnikova, I.N. Rotanova, M.M. Silantyeva, N.F. Kharlamova \\ Altai State University, Barnaul, Russian Federation \\ onb-olga@yandex.ru,rotanova07@inbox.ru,msilan@mail.ru,harlamovageo@rambler.ru
}

\begin{abstract}
The article discusses the importance of the factors of the formation of the landscape structure and landscape diversity for the creation of a natural park for the purpose of nature protection and the development of recreational nature management. The results of landscape studies performed in the process of substantiating the creation of a national park of regional significance "Foothills of Altai" in the vicinity of the resort of Belokurikha (Altai Krai) are presented. Functional zoning of the territory of the projected natural park with the allocation of zones of special protection, regulated recreational use and traditional nature management, as well as the buffer (buffer) zone is proposed.

Key words: natural park; landscape; landscape variety; nature protection; recreational wildlife management; functional zoning
\end{abstract}

\section{Факторы формирования ландшафтного разнообразия природного парка «Предгорье Алтая» и пути его сохранения}

\author{
О.Н. Барышникова, И.Н. Ротанова, М.М. Силантьева, Н.Ф. Харламова \\ Алтайский государственный университет, Барнаул, Российская Федерация \\ E-mail: onb-olga@yandex.ru,rotanova07@inbox.ru,msilan@mail.ru, harlamovageo@rambler.ru
}

\footnotetext{
В статье рассмотрены вопросы значимости факторов формирования ландшафтной структуры и ландшафтного разнообразия для создания природного парка с целью охраны природы и развития рекреационного природопользования. Представлены результаты ландшафтных исследований, выполненных в процессе обоснования создания в окрестностях курорта Белокуриха (Алтайский край) природного парка регионального значения «Предгорье Алтая». Предложено функциональное зонирование территории проектируемого природного парка с выделением зон особой охраны, регулируемого рекреационного использования и традиционного природопользования, а также охранной (буферной) зоны
} 
Baryshnikova, O.N. et al. (2017). Factors of the formation of.... Acta Biologica Sibirica, 2017, 3(3), 23-31

Ключевые слова: природный парк, ландшафт; ландшафтное разнообразие; охраны природы; рекреационное природопользование; функциональное зонирование

\section{Введение}

Географическое положение проектируемого в Алтайском крае природного парка «Предгорье Алтая» определило комплекс факторов, способствующих богатому биологическому и ландшафтному разнообразию территории его размещения. Богатое разнообразие всегда отражает обусловленность, как правило, нескольких факторов среды. Знание и учет факторов, обеспечивающих разнообразие биологических составляющих ландшафтов как экосистем и ландшафтных комплексов как геосистем на разных уровнях пространственной иерархии, является основой для разработки режимов природопользования и природоохранной деятельности. Территории с высоким биологическим и ландшафтным разнообразием наиболее выгодно использовать для организации охраняемых природных территорий и щадящего природопользования.

Разномасштабная пространственно-временная био- и ландшафтная мозаичность рассматривается как общее свойство геосистем, при этом геосистемы каждого уровня имеют различные ведущие факторы, определяющие степень георазнообразия. Формирование биологического (экосистемного) и ландшафтного (геосистемного) разнообразия определяется, прежде всего, георазнообразием территории (Разнообразие..., 2007).

Комплекс факторов, определяющих ландшафтное разнообразие территории расположения природного парка «Предгорье Алтая», включает:

- климатические условия - взаимодействие географических факторов климатообразования: режима поступления солнечной радиации, особенностей строения подстилающей поверхности и циркуляции воздушных мacc;

- историю формирования территории - установление связей (или изолированности) с другими геосистемами, характер и частоту смены режимов (тектонических, климатических и др.);

- литологическое разнообразие горных пород - определяющее создание разнообразных форм рельефа и, соответственно, способствующее формированию многообразия экологических ниш живых организмов и др.;

- позиционность и позиционные отношения - формирование ландшафтов в зоне контакта равнины и гор, лесов и степей, на стыке тектонических структур, на границе ареалов флоры и фауны и т.п.;

- степень расчлененности рельефа - формирование разнообразия форм рельефа, экспозиций, протекающих природных процессов и т.п.;

- гидрологические условия - наличие водных объектов и водный режим, закономерные изменения состояния водных ресурсов, способствующие формированию биологического разнообразия;

- биологическое разнообразие - один из ведущих, наиболее динамичных факторов, показатель жизнеспособности видов и экосистемы в целом;

- антропогенное воздействие - определяющее формирование модифицированных ландшафтов, в частности, культурных, а также рекреационно-ориентированную хозяйственную деятельность, характерную для природных парков.

Региональная специфика факторов формирования ландшафтного разнообразия определяется в соответствии со степенью сохранности, многообразия и устойчивости природных систем. Ландшафтное разнообразие является основой организации территориального экологического каркаса и/или экологической сети, преимущественно с созданием особо охраняемых природных территорий (Силантьева, Барышникова, Дьякова и др., 2017).

\section{Материалы и методы исследований}

В основе методологического подхода, использованного для анализа факторов ландшафтного разнообразия природного парка «Предгорье Алтая», лежит ландшафтная научная парадигма, основанная на представлении о пространстве как о мозаичной иерархической структуре, соподчиненности и корреляции между пространственными масштабами природных комплексов. В работе применялись различные типы полевых ботанико-географических и ландшафтных исследований: маршрутно-рекогносцировочный и маршрутнодетальный на ключевых участках. Геоботанические описания выполнялись по классической методике. При разработке классификации растительности использовался доминантный подход. Для проведения анализа факторов ландшафтного разнообразия проектируемого природного парка была создана ландшафтная карта масштаба 1:100 000 в цифровом формате, включенная в ГИС парка. Для полевых исследований были выбраны модельные участки в различных ландшафтах природного парка, в частности, наиболее используемых в рекреационном природопользовании; описано более 50 основных ключевых точек, проложено 10 маршрутов и ландшафтных профилей. Значительные размеры парка определили существенное разнообразие его ландшафтно-территориальных структур, которые возникли в результате взаимодействия локальных геологогеоморфологических, климатических, гидрологических и других природных факторов и процессов. 
Baryshnikova, O.N. et al. (2017). Factors of the formation of.... Acta Biologica Sibirica, 2017, 3(3), 23-31

\section{Результаты и их обсуждение}

Факторы формирования ландшафтного разнообразия и ландшафтная структура. Природный парк регионального значения «Предгорье Алтая» создается в юго-восточной предгорно-низкогорной части Алтайского края и охватит пространство, с запада и юго-запада ограниченное отрогами Ануйского, а с востока и юго-востока - Чергинского хребтов, северная граница пройдет по хорошо выраженному в рельефе участку тектонической зоны, отделяющему горную часть территории Алтайского края от равнинной (Предалтайской равнины), так называемому «фасу Алтая». Площадь парка составит более 40 тысяч га. Территория проектируемого природного парка располагается в границах Северо-Алтайской провинции Алтайской области Алтае-Саянской физикогеографической страны и по (Винокуров, 1980; Природно-мелиоративная оценка..., 1988) в СолонешенскоСарасинском физико-географическом районе, а согласно (Атлас..., 1978) выделяется в самостоятельный Белокурихинский физико-географический район.

Природные комплексы проектируемой ООПт «Предгорье Алтая», за исключением фрагментарных участков среднегорий в южной части, относятся в основном к низкогорному и горно-долинному подклассам горного класса ландшафтов. Это обусловливает возможность проявления в их структуре зональных и внутризональных особенностей широтного расположения территории парка, а также фактора высотной поясности. ООПт расположено в геолого-геоморфологическом плане на территории Белокурихинского гранитного массива, который простирается на большую часть природного парка. Особенности геологического развития данной территории обусловили ее геоморфологические условия и разнообразные формы рельефа. В пределах территории природного парка рельеф представлен денудационно-эрозионным низкогорьем с фрагментами реликтов поверхностей выравнивания и участком аккумулятивных полигенетических равнин.

Умеренно континентальный климат территории парка отличается теплым летом и мягкой умеренноснежной зимой. Климат формируется в результате взаимодействия географических факторов климатообразования: режима поступления солнечной радиации, особенностей строения подстилающей поверхности и циркуляции воздушных масс Средняя температура января $-16,5^{\circ} \mathrm{C}$, июля $-+20,2^{\circ} \mathrm{C}($ Харламова, 2013).

Территория проектируемого парка приурочена к бассейнам четырех рек - Песчаной, Черновой, Белокурихи и Даниловки. Реки несут свои воды с юга на север, рассекая территорию природного парка на 4 части, и придавая каждой из них своеобразный ландшафтный рисунок.

Флористический состав представлен осиново-пихтовыми и пихтовыми лесами с присутствием в напочвенном покрове разнообразных представителей неморальной флоры, выживших во время четвертичных оледенений. Вероятнее всего, территория природного парка располагается в пределах рефугиума - убежища тепло- и влаголюбивой флоры, существующего, в связи с особой конфигурацией отрогов Ануйского и Чергинского хребтов, преграждающих путь холодным арктическим вторжениям с севера и иссушающим воздушным массам с юга. Благодаря этому, в горных долинах существует особый микроклимат, благоприятный для произрастания и сохранения хвойно-широколиственных лесов.

В настоящее время широколиственные породы деревьев замещены осиной, занимающей ту же экологическую нишу, что и липа, когда-то широко представленная в лесных массивах. При благоприятных современных условиях липа может снова занять часть современного ареала осины и пихты.

Своеобразие абиотических факторов определило разнообразие растительного покрова и животного населения ландшафтов природного парка. Каждому из типов ландшафтов (степному, лесостепному или лесному) соответствует специфический набор населяющих их видов животных и растений. Именно данная особенность биоразнообразия определяет актуальность сохранения естественной ландшафтной обстановки на территории проектируемой ООПТ «Предгорье Алтая».

Современная биота характеризуется как уникальностью, так и типичностью для низкогорий и среднегорий Северного Алтая, имея черты реликтовости. Флора представлена 648 видами, относящимися к 335 родам и 69 семействам. В пределах территории выделены: лесной и горно-лесной, луговой и горно-луговой, луговостепной, кустарниковый, степной и азональный комплексы видов, скальная, водная и антропогенно-измененная растительность. Отмечен 131 вид лишайников, относящихся к 20 родам, в том числе найдены очень редкие уязвимые виды: пиксине соредиозная (Pухіne sorediata), лептогиум Бурнета (Leptogium burnetiae Dodge) и лобария легочная (Lobaria pulmonaria). Обнаружен ряд редких для флоры Алтайского края видов растений: папоротник диплазиум сибирский (Diplazium sibiricum), лук желтеющий (Allium flavescens), леерсия рисовидная (Leersia oryzoides), фиалка Селькирка (или фиалка теневая Vīola selkīrkii) и др. Два вида являются эндемиками Алтае-Саянской горной страны: смолевка вздутая (Sileneturgida) и зубянка сибирская (Dentariasibirica) (Елесова, Овчарова, Силантьева, 2016; Ротанова, Васильева, 2015).

Наибольший природоохранный и научный интерес вызывает флористический комплекс видов черневых (пихтовых Abies sibirica) и производных от них лесов, содержащий 34 вида-реликта широколиственных лесов миоцен-плиоцена.

На территории планируемого природного парка присутствуют 2 вида растений (кандык сибирский Erythronium sibiricum, ковыль перистый Stipa pennata) и 3 вида лишайников (Leptogium burnetiae, Lobaria pulmonaria, Pyxine sorediata), занесенных в Красную книгу Российской Федерации (2008). 
Baryshnikova, O.N. et al. (2017). Factors of the formation of... Acta Biologica Sibirica, 2017, 3(3), 23-31

Выявлено 5 видов лишайников, занесенных в Красную книгу Алтайского края (2006, 2016): гетеродермия красивая (Heterodermia speciose), лобария ямчатая (Lobaria scrobiculata), пармелина липовая (Parmelina tiliacea), рамалина Рослера (Ramalina Roesleri), рамалина китайская (Ramalina sinensis).

Помимо лишайников, в Красную книгу Алтайского края $(2006,2016)$ занесены 10 видов сосудистых растений: рябчик шахматный (Fritillaria meleagris), наперстянка крупноцветковая (Digitalis grandiflora), колокольчик крапиволистный (Campanula trachelium), башмачок капельный (Cypripedium guttatum), тюльпан поникающий (Tulipa patens), волчеягодник обыкновенный (Daphne mezereum), Адонис сибирский (Adonis sibirica), пион уклоняющийся (Paeonia anomala).

Встреченные виды позвоночных являются типичными для нашей территории и достаточно многочисленными, что свидетельствует о благоприятных условиях среды обитания. Были выявлены 3 вида амфибий (из пяти, обитающих на территории края) и 6 видов рептилий из восьми, встречающихся в крае (настоящая, прыткая и живородящая ящерицы, уж обыкновенный, узорчатый полоз, обыкновенная гадюка и щитомордник).

Обнаружено 132 вида птиц, относящихся к 14 отрядам и 35 семействам. Видовой состав очень разнообразен вследствие биотопического разнообразия и разновысотности территории планируемого парка.

Отмечено обитание 28 видов млекопитающих (на территории Алтайского края больше 90) из 6 отрядов и 14 семейств. Наиболее разнообразно представлены виды из отрядов Насекомоядные (землеройки), Грызуны полевки (лесные и серые) и Хищные (семейство куньи).

Среди ихтиофауны - сибирский хариус и обыкновенный таймень, щука, пескарь, серебряный карась, гольян, плотва, уклейка, пресноводный окунь, а также вид, включенный в Красную Книгу МСОП и Алтайского края (2016) минога сибирская (Lethenteron kessleri).

По фауне беспозвоночных имеются сведения по чешуекрылым, жукам, полужесткокрылым, веснянкам, равнокрылым и стрекозам, паукам. Обнаружено 149 видов чешуекрылых, относящихся к 16 семействам. По экспертной оценке отряд Lepidoptera содержит до 800 видов, типичных для лесных низкогорий Северного Алтая. Установлены местонахождения и местообитание 20 видов пауков, относящихся к 7 семействам, что составляет не более чем 10\% от реального количества видов пауков, населяющих территорию планируемой ООПТ.

На территории планируемого парка «Предгорье Алтая» обитает 20 видов животных, занесенных в Красные книги Алтайского края (2006, 2016), России (2001) и Международного союза охраны природы (МСОП). Среди них 1 вид из группы круглоротых (минога Lethenteron kessleri), 1 вид из класса амфибий (сибирский углозуб Salamandrella keyserlingii), 12 видов птиц: беркут (Aquila chrysaetos), степной орел (Aquila nipalensis), сапсан (Falco peregrinus), могильник (Aquila heliaca), большой подорлик (Aquila clanga), филин (Bubo bubo) и др., 4 вида млекопитающих: кабарга (Moschus moschiferus), три вида летучих мышей и 2 вида бабочек: аполлон обыкновенный (Рarnassius apollo), перламутровка непарная (Argynnis sagana).

На территории проектируемого природного парка выявлены малонарушенные уникальные природные комплексы (сосновые и березовые леса на гранитах, луговые степи, низинные солонцеватые луга с рябчиком, мезопетрофитон), а также исчезающие, редкие и уникальные сообщества и экосистемы - черневые леса.

В процессе взаимодействия компонентов природы и факторов окружающей среды сформировалась уникальная ландшафтная структура территории проектируемого природного парка. На большей ее части существенное влияние на формирование ландшафтов оказывает значительное атмосферное увлажнение, которое перераспределяется в соответствие с геоморфологическим устройством поверхности. Это приводит к тому, что здесь наблюдается проявление таких закономерностей, как зональность, ярусность и высотная поясность. Также наблюдаются барьерные (на наветренных хорошо увлажненных склонах) и барьерогенные, сформировавшиеся в орографической тени, природно-территориальные комплексы.

Ландшафтная структура природного парка представлена 6-ю типами местностей, включающими 16 таксонов групп урочищ и 71 таксон, выделенный как урочища (рис. 1).

Тип местности пенепленизированные останцово-грядовые низкогорья с лессовыми покровами, березовыми сосновыми лесами на горно-лесных и луговыми степями на горно-лугово-черноземных почвах (1) включает: останцово-грядовые водоразделы (1.1.1) и прилегающие к ним крутые склоны (1.1.2) с сосновыми и осиновоберезовыми лесами на маломощных горно-лесных серых почвах; крутые склоны с остепненными лугами на дерново-луговых почвах (1.1.3); пологие и средней крутизны склоны с сосновыми лесами на горно-лесных оподзоленных почвах (1.1.4); останцовые вершины с пихтовыми и вторичными березово-осиновыми лесами на горно-лесных маломощных серых почвах (1.1.5); останцовые поверхности с луговой растительностью и прилегающие к ним склоны с березовыми лесами на маломощных горно-луговых и горно-лесных почвах (1.1.6); пологие склоны с пихтовыми лесами (1.1.7) и березово-сосново-осиновыми лесами (1.1.8) на горно-лесных темносерых почвах; склоны низкогорий крутые и средне крутые (1.2.1), пологие (1.2.2) с березовыми или сосновыми лесами на горно-лесных серых почвах в сочетании с суходольными лугами на лугово-черноземных почвах; пологие склоны с разреженными сосновыми лесами на горно-лесных серых оподзоленных почвах (1.2.3), с закустаренными луговыми степями в сочетании с молодыми сосново-березовыми лесами на горных луговочерноземных почвах (1.2.4). 
Baryshnikova, O.N. et al. (2017). Factors of the formation of... Acta Biologica Sibirica, 2017, 3(3), 23-31

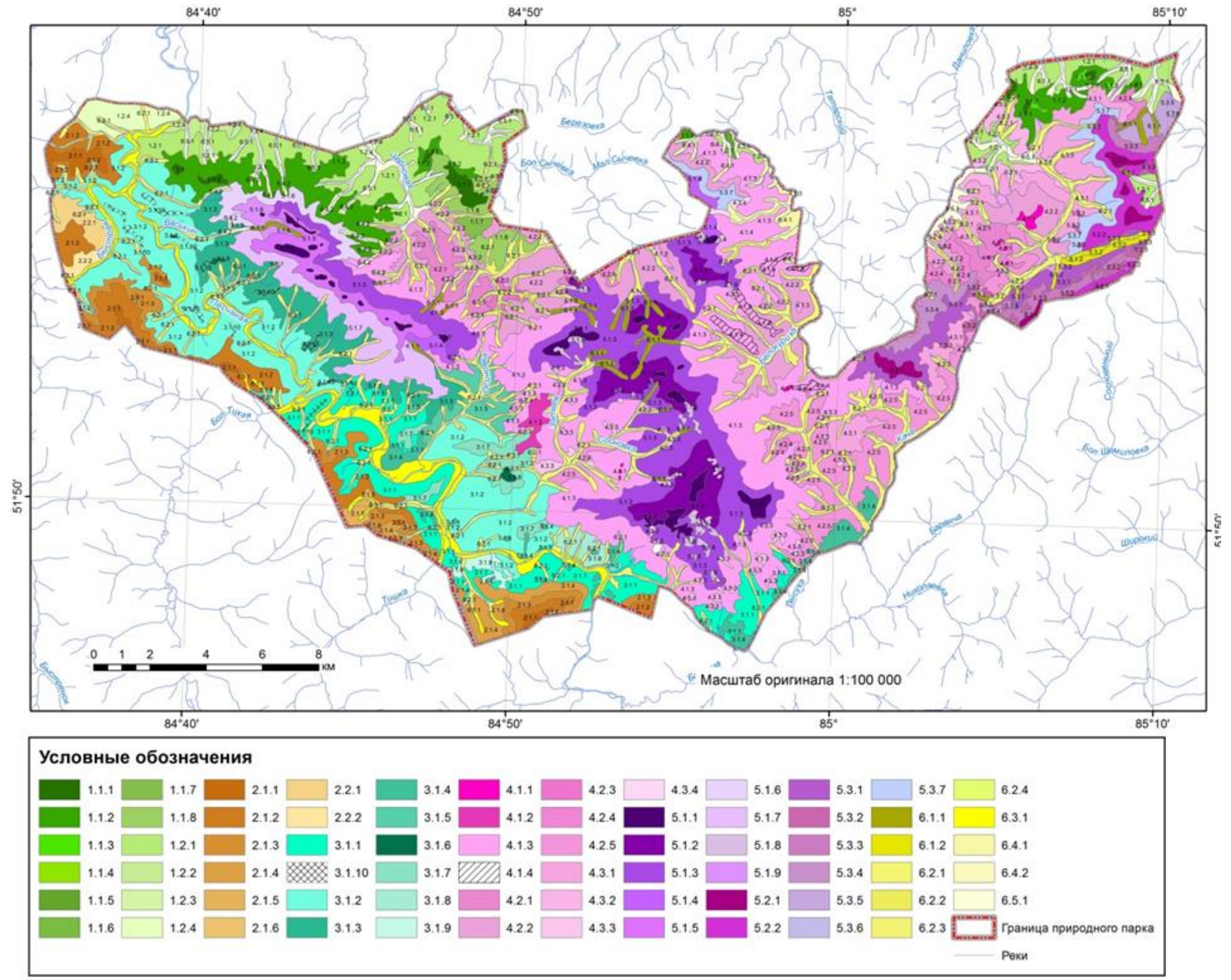

Рис. 1. Ландшафтная структура природного парка «Предгорье Алтая». Масштаб оригинала 1:100 000.

Автор: Барышникова О.Н. Техническое исполнение: Дьякова Г.С., Останин О.В.

Тип местности пенепленизированные останцово-грядовые низкогорья с лессово-щебнистыми покровами, покрытые закустаренными березово-сосновыми лесами в сочетании с лесными лугами и луговыми степями на горных серых лесных почвах (2) включает: останцово-грядовые водоразделы с разреженными остепненными березово-сосновыми лесами в сочетании с выходами коренных пород и кустарниковыми зарослями на горных скелетных почвах (2.1.1); крутые и средней крутизны склоны с выходами скальных пород с березово-сосновыми лесами на горно-лесных серых почвах в сочетании с лесными лугами на горно-луговых почвах (2.1.2); склоны средней крутизны с березовыми и сосновыми лесами на горных серых лесных почвах (2.1.3); пологие склоны с лесными лугами на горно-лесных серых почвах и луговыми степями на горных лугово-черноземных почвах (2.1.4); водораздельные поверхности с парковыми сосново-березовыми лесами в сочетании с суходольными лугами на горно-лесных серых почвах (2.1.5); крутые и отвесные склоны с зарослями кустарников на горноскелетных почвах (2.1.6); склоны средней крутизны с сосново-осиново-березовыми лесами на горно-лесных серых почвах (2.2.1) в сочетании с остепненными лесами и лесными лугами на горно-лесных темно-серых почвах (2.2.2).

Тип местности денудационно-эрозионные низкогорья с лессовыми и каменисто-щебнистыми покровами с сосновыми, березовыми и осиновыми лесами на горно-лесных темно-серых почвах в сочетании с разнотравными лугами на дерново-луговых почвах (3) включает: склоны средней крутизны и пологие с сосновыми лесами на горнолесных серых оподзоленных почвах (3.1.1); крутые придолинные склоны с осиново-сосново-березовыми лесами на темно-серых лесных почвах (3.1.2); крутые изрезанные долинами постоянных и временных водотоков склоны с сосново-березовыми и березово-сосновыми лесами на горно-лесных маломощных серых оподзоленных почвах (3.1.3); пологие и средней крутизны склоны с остепненными лугами на лугово-черноземных почвах (3.1.4); пологие и средней крутизны придолинные склоны с березовыми и сосновыми лесами на горно-лесных темносерых почвах (3.1.5); останцовые вершины с сосновыми лесами на горно-лесных маломощных серых почвах (3.1.6); низкие водоразделы с парковыми лесами на горно-лесных серых почвах (3.1.7); пологие и средней крутизны придолинные склоны с лиственничными лесами в сочетании с сосново-березовыми лесами и суходольными лугами на горно-лесных серых почвах (3.1.8); наклонные поверхности с луговыми степями на 
Baryshnikova, O.N. et al. (2017). Factors of the formation of... Acta Biologica Sibirica, 2017, 3(3), 23-31

горных лугово-черноземных почвах (3.19); низкие водоразделы с прилегающими пологими склонами с осиновососново-березовыми лесами на темно-серых лесных почвах (3.1.10).

Тип местности денудационно-эрозионные низкогорья с лессовыми и каменисто-щебнистыми покровами с сосновыми и пихтовыми лесами на бурых и темно-серых горных лесных почвах в сочетании с мелколиственными лесами и разнотравными лесными лугами на дерново-луговых почвах (4) включает: останцовые вершины с пихтовыми лесами на горно-лесных серых почвах (4.1.1); невысокие водоразделы с березово-осиново пихтовыми лесами на горно-лесных серых почвах (4.1.2); крутые и средней крутизны склоны с сосново-березово-осиновопихтовыми и осиново-пихтовыми лесами на горно-лесных бурых почвах (4.1.3); водоразделы с сосново-березовоосиново-пихтовыми и осиново-пихтовыми лесами на горно-лесных бурых почвах (4.1.4); пологие и средне крутые склоны с пихтовыми, березовыми, осиновыми лесами на горно-лесных серых почвах в сочетании с низинными лугами на дерново-луговых почвах (4.1.5); низкие водоразделы и прилегающие к ним пологие склоны с осиновыми, сосново-осиново-березовыми лесами на горно-лесных темно-серых почвах (4.2.1); пологие и средне крутые склоны с пихтовыми, березовыми, осиновыми лесами на горно-лесных серых почвах (4.2.2); пологие придолинные склоны с закустаренными злаково-чемерицевыми лугами на дерново-луговых почвах (4.2.3); склоны средней крутизны с молодыми вторичными осиновыми и пихтово-осиновыми лесами на горно-лесных серых почвах (4.2.4); придолинные склоны средней крутизны с пихтовыми, березово-осиново-пихтовыми лесами на горно-лесных серых почвах (4.2.5); крутые и средней крутизны склоны с сосновыми, осиновыми и березовыми лесами на горно-лесных серых почвах (4.3.1); средней крутизны придолинные склоны с сосново-осиновоберезовыми лесами на горно-лесных серых почвах (4.3.2); пологие и средне крутые склоны с разнотравными лугами на горно-луговых почвах (4.3.3); крутые и отвесные склоны с зарослями кустарников и отдельными деревьями на горно-скелетных почвах (4.3.4).

Тип местности останцово-гребневидные низкогорья с мощным щебнистым покровом с пихтовыми, осиновыми, березово-осиновыми папоротниковыми и крупнотравными лесами на горных серых лесных почвах (5) включает: гребневидные водоразделы с выходами скальных пород с разреженными пихтовыми лесами на горных скелетных почвах (5.1.1); крутые и средне крутые склоны с сосново-березово-осиново- пихтовыми лесами на маломощных горно-лесных серых почвах (5.1.2); крутые и средней крутизны склоны с сосново-березово-осиновопихтовыми лесами на темно-серых лесных почвах (5.1.3); склоны с пихтово-сосновыми лесами на темно-серых лесных почвах (5.1.4); приподнятые поверхности выравнивания с выходами коренных пород с пихтовыми лесами в сочетании с зарослями кустарников на горно-скелетных почвах (5.1.5); средне крутые склоны с сосновоберезово-осиновыми лесами на маломощных горно-лесных серых почвах (5.1.6); крутые склоны с выходами коренных пород с сосново-березово-осиновыми лесами и лесными лугами на маломощных горно-лесных серых почвах (5.1.7); крутые склоны с разнотравными лугами на горно-луговых дерновых почвах (5.1.8); пологие склоны с выходами коренных пород, образующими отвесные уступы, с сосново-березовыми лесами и лесными лугами горно-лесных серых почвах (5.1.9); останцовые поверхности с лиственничными и пихтовыми лесами на маломощных горно-лесных серых почвах (5.2.1); крутые склоны с пихтовыми и осиново-березовыми лесами на маломощных горно-лесных серых почвах (5.2.2); крутые склоны низкогорий с осиново-сосновыми березовыми лесами на маломощных горно-лесных серых почвах (5.3.1); средне крутые склоны низкогорий с лугами, вышедшими из-под леса, и посадками сосны на горно-лесных серых почвах (5.3.2); пологие склоны низкогорий с пихтовыми и березово-пихтовыми лесами на горно-лесных серых почвах (5.3.3); пологие склоны низкогорий с осиново-березовыми лесами на горно-лесных темно-серых почвах (5.3.4); средне крутые склоны низкогорий с осиновыми и березовыми лесами на горно-лесных серых почвах (5.3.5); останцовые водораздельные поверхности с березово-осиновыми лесами на маломощных горно-лесных серых почвах (5.3.6); средне крутые склоны с пихтово-осиново-березовыми и сосновыми лесами на горно-лесных маломощных серых почвах (5.3.7).

Тип местности горно-долинные низкогорий и предгорий (6) включает: V-образные долины рек останцовогребневидных низкогорий, выработанные в гранитах с низинными лугами и прирусловыми лесами на примитивных дерново-луговых почвах (6.1.1); расширенные V-образные долины, выработанные в известняках с низинными лугами и прирусловыми лесами на примитивных аллювиальных почвах (6.1.2); долины рек денудационно-эрозионных низкогорий, выработанные в гранитных породах, с молодыми прирусловыми леса ми на пойменных слоистых почвах (6.2.1); заболоченные долины малых рек с разнотравно-злаковыми закустаренными лугами на дерново-слоистых почвах (6.2.2); долины рек, выработанные в известняках, с прирусловыми закустаренными лесами и низинными лугами на дерново-слоистых почвах (6.2.3); долины ручьев и временных водотоков с разнотравно-злаковыми закустаренными лугами на дерновых почвах (6.2.4); поймы рек с прирусловыми закустаренными осиновыми, тополевыми и березовыми лесами на примитивно-слоистых почвах (6.3.1); террасовые комплексы с злаково-разнотравными низинными лугами в сочетании с осиновыми, березовыми или пихтовыми лесами на серых оподзоленных почвах (в масштабе карты не читаются) (6.3.2); Vобразные долины верховий малых рек пенепленизированных останцово-грядовых низкогорий с низинными лугами и прирусловыми пихтовыми лесами на примитивных дерново-луговых почвах (6.4.1); V-образные долины с низинными лугами и прирусловыми березово-осиновыми лесами на примитивных дерново-луговых почвах (6.4.2); поймы рек с прирусловыми осиновыми, березовыми и пихтовыми лесами в сочетании с разнотравнозлаковыми лугами на аллювиальных дерново-слоистых почвах (6.5.1); террасовые комплексы с злаково- 
Baryshnikova, O.N. et al. (2017). Factors of the formation of.... Acta Biologica Sibirica, 2017, 3(3), 23-31

разнотравными лугами на дерново-луговых почвах в сочетании с сосново-осиново-березовыми и пихтовыми лесами на серых оподзоленных почвах (в масштабе карты не читаются) (6.5.2).

Пути сохранения ландшафтного разнообразия и выполнения природоохранного императива. Разнообразные природные ландшафты с богатой флорой, наличие горных, предгорных и равнинных участков, водных объектов, выходы горных пород в виде останцов и скал, относительно небольшой перепад высот, объекты историко-культурной и эстетической ценности в совокупности формируют значительный потенциал туристско-рекреационных ресурсов. Территория планируемого природного парка интересна для организации различных видов туристско-рекреационной деятельности (Харламова, Ротанова, Васильева и др., 2016; Харламова, Силантьева, Барышникова и др., 2016). Однако, первостепенной задачей природного парка является природоохранный императив. Для снятия противоречий между природоохранной функцией ООпт и рекреационными видами природопользования разработаны предложения по функциональному зонированию территории природного парка, предполагающие ее разделение на участки с определенным приоритетным назначением (функцией), с различными режимами охраны и использования (рис. 2).

На территории природного парка предполагается создание зон особой охраны, регулируемого рекреационного использования и традиционного природопользования.

Зона особой охраны («особо охраняемая зона») - обеспечивает условия для сохранения природных комплексов при строго регулируемом рекреационном и хозяйственном использовании. Здесь охраняются как типичные, так и уникальные и редкие экосистемы и ландшафты, отличающиеся высокой степенью уязвимости: различные варианты черневых лесов и их производных, сосновые и березовые леса на гранитах, низинные богаторазнотравные луга верховий р. Черновая. Зона состоит из двух фрагментов: а) охватывающего горы Черная Грива и Амбарчики, б) охватывающего горы Малая Синюха и Синюха и протягивающегося до горы Листвяная. В этой зоне запрещается любая деятельность, влекущая за собой изменения исторически сложившегося природного ландшафта, снижение или уничтожение экологических, эстетических и рекреационных качеств парка.

Зона регулируемого рекреационного использования. Здесь обеспечиваются условия для осмотра достопримечательностей и кратковременного отдыха. Зона разбита на несколько участков, каждый из которых доступен и привлекателен для туристов. В данную зону входят фрагменты всех типов местности, представленных на территории природного парка. Внутри зоны регулируемого рекреационного использования выделены подзоны: обслуживания посетителей и коммунально-хозяйственная:

а) подзона обслуживания посетителей - располагается вдоль границ курорта Белокуриха-2, в районах охотничьих зимовий и строящихся туристических баз. Природные комплексы зоны будут сохраняться, благодаря реализации планов создания адаптивных проектов по ландшафтному обустройству территории;

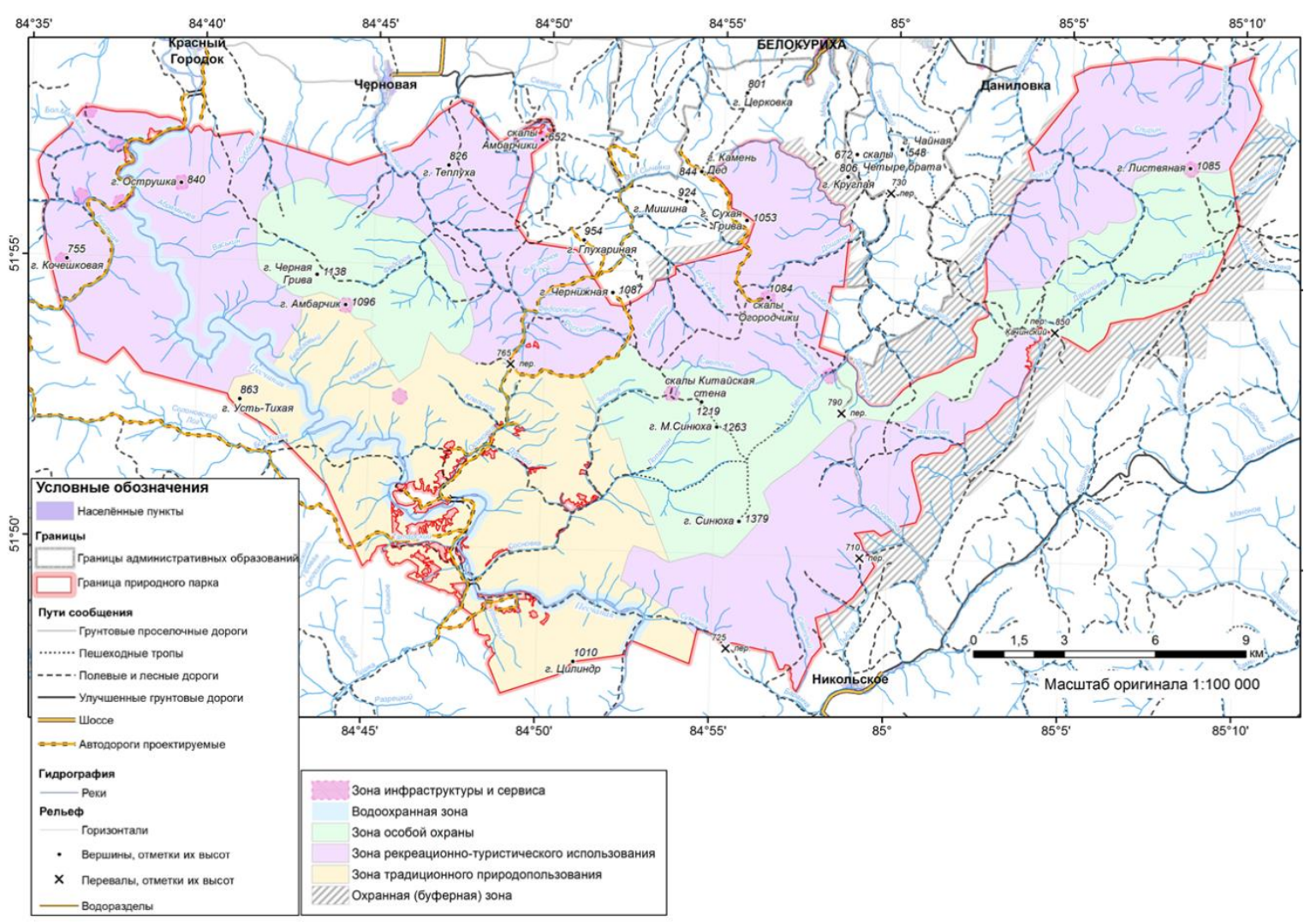

Рис. 2. Схема функционального зонирования природного парка «Предгорье Алтая» с нанесением объектов туристского интереса. Масштаб оригинала 1:100 000.

Составлена по материалам Силантьевой М.М., Барышниковой О.Н., Ротановой И.Н., Останина О.В., Харламовой Н.Ф., Елесовой Н.В., Дьяковой Г.С. и др. Техническое исполнение: Г.С. Дьякова, О.В. Останин 
Baryshnikova, O.N. et al. (2017). Factors of the formation of... Acta Biologica Sibirica, 2017, 3(3), 23-31

б) коммунально-хозяйственная подзона - район размещения существующих на территории парка туристских комплексов и гостевых домов, а также объектов их социальной и жилищно-коммунальной инфраструктуры. Управление территорией этой функциональной подзоны должно быть направлено на регулирование использования природных ресурсов, контролирование соблюдения установленных правил и норм природопользования.

Зона традиционного природопользования - предназначена для сохранения режима сложившегося землепользования (сенокошение, выпас скота, выращивание сельхозпродукции, рыболовство, рыбоводство, охота и др.). В этой зоне необходимо проведение мероприятий, предотвращающих снижение биологического разнообразия и пастбищной дигрессии.

Кроме того, предложено создание для природного парка охранной (буферной) зоны, шириной до 300 м, расположенной фрагментарно в местах возможной экологической напряженности, связанной с антропогенным воздействием. Местоположение и ширина буферной зоны определяются, исходя из непосредственного примыкания и соседства с землями населенных пунктов; промышленных, транспортных и иных хозяйственных объектов, месторождений и проявлений полезных ископаемых, линейных объектов и инженерных коммуникаций с учетом их возможного негативного воздействия на окружающую среду и экосистемы природного парка.

\section{Выводы}

Именно ландшафты как носители природного разнообразия впервые были избраны в качестве ключевых объектов проектирования и создания новой ООПт в Алтайском крае. Ландшафтное разнообразие территории расположения природного парка «Предгорье Алтая» определяет комплекс факторов, характеризующих его местоположение и ландшафтообразующие условия. В ландшафтном отношении парк расположен в пределах Северо-Алтайской физико-географической провинции, для территории которой характерна разнообразная мозаика природных комплексов, включающая сочетание на сравнительно небольшой территории пенепленизированных останцово-грядовых лесостепных низкогорных ландшафтов, денудационно-эрозионных лесных низкогорий в совокупности с ландшафтами горно-долинных низкогорий и предгорий.

Цель создания природного парка «Предгорье Алтая»- сохранение горнолесных ландшафтов юго-восточной части Алтайского края и дальнейшее развитие туристско-рекреационных возможностей курорта федерального значения Белокуриха.

В пределах территории проектируемого природного парка выявлены уникальные ландшафты черневой тайги, в структуре которой существенную роль играют представители третичной флоры. Экологическая ценность ландшафтов территории определяется еще и тем, что на ней обнаружены представители видов животных и растений, занесенных в Красные книги различного уровня.

В качестве одного из ядер экологического каркаса Алтайского края территория природного парка может выполнять широкий спектр функций - от средообразующих до информационных. Планируется, что создание парка «Предгорье Алтая» будет способствовать оптимизации рекреационного использования территории путем осуществления подобной деятельности на основе природоохранного законодательства и экологического нормирования.

\section{References}

Bolotova, N.L., Borisov, M.Ya., Dumnich, N.V. et al. (2007). Variety of landscapes of the national park "Russian North". Vologda. GOU VPO "Vologda State Pedagogical University" (in Russian).

Silantyeva, M.M., Baryshnikova, O.N., Dyakova, G.S., Ostanin, O.V., Rotanova, I.N., Kharlamova, N.F. (2017). Natural Park "Foothills of Altai" - a basic element of the ecological framework of the Altai Krai. The role of the Altai Territory in the ecological framework of the Russian Federation: a collection of abstracts of the scientific and practical conference. Barnaul: Printing house of the Administration of the Altai Krai Government, 51-53 (in Russian).

Vinokurov Yu.I. (1980). Landscape indicators of engineering and hydrogeological conditions of the predaltaian plains. Novosibirsk, Science. Academy of Sciences. Siberian Brench (in Russian).

Natural-meliorative assessment of lands in the Altai Krai / Yu.I. Vinokurov, Yu.M. Tsimbaly et al., Irkutsk, 1988 (in Russian).

Atlas of the Altai Territory (1978). Moscow- Barnaul, GUGK under the USSR Council of Ministers, 1. (in Russian).

Kharlamova, N.F. (2013). Climate of the Altai region: textbook. Barnaul: Publishing house Altai University (in Russian).

Elesova, N.V., Ovcharova, N.V., Silanteva, M.M. (2016). General characteristics of vegetation of the projected natural park "Belokurikhinsky". Acta Biologica Sibirica, 2 (4), 52-58 (in Russian).

Rotanova, I.N., Vasilyeva, O.A. (2015). Mapping of phytodiversity in the design of the Belokurikha nature park. Geography and Nature Management of Siberia: a collection of articles. G.Ya. Baryshnikov (Ed.), Barnaul, Publishing house Altai University, 19, 171-177 (in Russian).

The Red Book of the Russian Federation (Plants and mushrooms) (2008). Ministry of Natural Resources and Ecology of the Russian Federation; The Federal Service for Supervision in the Sphere of Nature Management; RAS; Russian Botanical 
Baryshnikova, O.N. et al. (2017). Factors of the formation of.... Acta Biologica Sibirica, 2017, 3(3), 23-31

Society; Moscow State University. M.V. Lomonosov; Ch. Editorial Board: Yu. P. Trutnev et al.; Comp. R.V. Kamelin et al., Moscow, The Partnership of Scientific Publications KMC (in Russian).

Red Book of the Altai Krai (2006). Rare and endangered plant species. Barnaul, Open Society "IPP "Altai " (in Russian).

Red Book of the Altai Krai (2016). Rare and endangered species of plants and fungi, 1, Barnaul, Publishing house Altai University, (in Russian).

Red Data Book of the Altai Krai. (2006). Rare and endangered species of animals, 2, Barnaul, Open Society "Altay " (in Russian).

Red Book of the Altai Krai. (2016). Rare and Endangered Species of Animals, 2, Barnaul, Publishing house Altai University (in Russian).

Red Data Book of the Russian Federation (Animals) (2001). RAS; Ch. Rare: V.I. Danilov-Danilyan et al., Moscow, AST: Astrel (in Russian).

Kharlamova, N.F., Rotanova, I.N., Vasilyeva, O.A., Gaida, V.V., Batalov, R.O., Kazartseva, O.S. (2016). Tourist and recreational resources of the natural park "Foothills of Altai" created in the Altai Krai. Possibilities of development of regional studies and tourism of the Siberian region and adjacent territories. Collection of scientific articles on the results of the Sixteenth International Scientific and Practical Conference, dedicated to the memory of the Honorary Chairman of the RGO LLP, prof. P.A. Okisheva, 1-2 November 2016 Tomsk, 243-245 (in Russian).

Kharlamova, N.F., Silantyeva, M.M., Baryshnikova, O.N., Rotanova, I.N., Elesova, N.V., Petrov, V.Yu. (2016). Ecologicalcognitive tourism in the protected areas of the Altai Krai (on the example of the projected natural park "Foothills of the Altai"). Proceedings of the ARB RGS, 3 (42), 5-12 (in Russian).

\section{Citation:}

Baryshnikova, O.N., Rotanova, I.N., Silantyeva, M.M., Kharlamova, N.F. (2017). Factors of the formation of landscape diversity of the natural park "Foothills of the Altai" and ways to preserve it. Acta Biologica Sibirica, 3 (3), 23-31.

Submitted: 21.08.2016. Accepted: 30.10.2017

cross ref $\underline{\text { http://dx.doi.org/10.14258/abs.v3i3.3612 }}$

(C) 2017 by the authors. Submitted for possible open access publication under the terms and conditions of the

Creative Commons Attribution (CC BY) license (http://creativecommons.org/licenses/by/4.0/). 